\title{
Oenothera species and Borago officinalis: sources of gamma-linolenic acid
}

\author{
B. G. Muuse ${ }^{1, *}$, M. L. Essers ${ }^{1}$ and L. J. M. van Soest ${ }^{2}$ \\ ${ }^{1}$ State Institute for Quality Control of Agricultural Products (RIKILT), P.O. Box \\ 230, NL 6700 AE Wageningen, Netherlands \\ ${ }^{2}$ Centre for Genetic Resources The Netherlands (CGN) and Foundation for Agri- \\ cultural Plant Breeding (SVP), P.O. Box 224, NL 6700 AE Wageningen, Nether- \\ lands
}

Received 8 January 1988; accepted 12 July 1988

Key words: Oenothera, Borago officinalis, seed oil, fatty acids, gamma-linolenic acid

\section{Summary}

Seed samples of Oenothera species and of Borago officinalis, cultivated in 1986, were analysed to determine their fatty acid composition and in particular the gamma-linolenic acid (GLeA) content. In B. officinalis $7.1 \%$ GLeA was found whereas in Oenothera species the average was $2.3 \%$. The mean content of oil in the seeds was $30.8 \%$ and $21.2 \%$, respectively. The GLeA content in both seed types was positively correlated with the seed oil $(r>0.8)$. The fatty acid composition in the oil showed only little variation within the different Oenothera species grown in that particular year. The soil type, sand or clay, did not significantly influence the GLeA and other fatty acid contents. It was concluded that the production of GLeA from $B$. officinalis can be as much as three times higher than in Oenothera species considering similar seed yields for both crops and neglecting the poor seed retention of $B$. officinalis. The high level of GLeA emphasises the quality of the oil from $B$. officinalis in comparison to evening primrose when used to compensate a lack of GLeA in man caused by $\Delta 6$-linoleic desaturase deficiency diseases and is of interest as alternative for the microbiological GLeA produce.

\section{Introduction}

Gamma-linolenic acid (GLeA) (C18:3, n-6,9,12; all cis) is an essential fatty acid and is normally produced in human beings through desaturation of linoleic acid

\footnotetext{
* Present address: Institute for Storage and Processing of Agricultural Produce (IBVL), P.O. Box 18, NL 6700 AA Wageningen, Netherlands
} 
(LA) by $\triangle 6$-LA desaturase in liver. GLeA must be supplied in the diet in cases of enzyme deficiencies since GLeA acts as precursor for bis-homo-GLeA and arachidonic acid from which indispensable compounds are produced in the body such as prostaglandins PGE1 and PGE2, prostacyclins and tromboxanes (Paccalin et al., 1984; van Dorp, 1983; Horrobin et al., 1983). GLeA is also found in human milk fat (Gibson et al., 1981) reflecting the occurrence of this fatty acid in man.

Most of the commercial sources of GLeA currently available for pharmaceutical purposes is the oil of evening primrose. Oenothera lamarckiana Ser and $O$. biennis are commonly breeded in the Netherlands. Plant materials were surveyed to search for new GLeA sources by Lacombe et al., 1985; Pina et al., 1984; Traitler et al., 1984; Wolf et al., 1983; Miller et al., 1968; Kleiman et al., 1964; Earle et al., 1959. They have described a lot of seed species with this essential fatty acid. In Oenograceae ca $2.5 \%$ GLeA is found in the seed, whereas Boraginaceae and especially $B$. officinalis contain up to $7 \%$ GLeA (Kleiman et al., 1964).

During recent years, breeding and agronomical research was conducted in the Netherlands with Oenothera species and $B$. officinalis. Genetic resources from all over the world were introduced to investigate the possibilities for commercial production of vegetable GLeA. During the early eighties increasing interest exist in cultivation of GLeA crops in the Netherlands (1986: 800 ha evening primrose and 80 ha borage). In the present paper, data are presented of oil content and fatty acid composition of the seed oils from different species of Oenothera, in particular $O$. biennis and $O$. lamarckiana, and of $B$. officinalis. The effect of different soil types on the chemical composition of the seed will be discussed.

\section{Materials and methods}

The Centre for Genetic Resources The Netherlands (CGN) has recently evaluated some 200 accessions of eight different subgenera of the genus Oenothera and 11 accessions of $B$. officinalis as part of a program on new crop development with main emphasis on industrial oilseeds (van Soest, 1987). The collections of Oenothera were grown in 'single' plots partly on light sandy soils and partly on heavy clay. Five different species of the same origin (accessions) were grown on both soil types. The 11 accessions of $B$. officinalis were only grown on the sandy soil. A group of 62 most promising Oenothera accessions, of which 57 belong to the same subgenera, were selected on the basis of performance. All seed samples were cleaned, dried at $22{ }^{\circ} \mathrm{C}$ to approximately $8 \%$ moisture content, sealed in laminated aluminium bags and analysed for oil and fatty acids.

\section{Oil content}

Oil content was determined by simultaneous steel ball grinding and extraction with petroleum ether $40 / 60$ for $10 \mathrm{~min}$, followed by soxhlet extraction and repetition of the whole procedure. After evaporation of the solvent, the oil was dried at $100{ }^{\circ} \mathrm{C}$ for $1 \mathrm{~h}$. 


\section{Fatty acid composition}

An aliquot of the petroleum ether, containing ca $100 \mathrm{mg}$ oil, was taken just before evaporation of the solvent, to prevent oxidation of GLeA, and used for gas-chromatographic analysis. The fatty acid methyl esters (FAME) were prepared by transesterification of the glyacyls with $200 \mu \mathrm{l} 2 \mathrm{~N}$ potassium hydroxide in methanol and shaking for $20 \mathrm{~s}$ (IUPAC, 1984a). The gas-chromatographic analyses were performed with a Varian Serie 3700 gas chromatograph with automatic injection system and split injector. The FAME's were separated isothermal at $215^{\circ} \mathrm{C}$ on a $25 \mathrm{~m}$ $\times 0.22 \mathrm{~mm}$ fused silica capillary column of CP WAX 57 Chemical Bounded (Chrompack, Middelburg, NL), according to the principles of IUPAC (1984b). The peaks were identified using analytical-grade FAME's and the results were quantified with the recently certified reference material RM162 (soya-maize blend) of the Bureau Communautaire de Référence ${ }^{1}$. This leads to results with a level-independant standard deviation less than $0.1 \%$.

\section{Results and discussion}

\section{Oil content and other properties}

The oil content of the 11 accessions of $B$. officinalis varied from 24.0 to $34.0 \%$, whereas in 27 samples of the common cultivated $O$. biennis and $O$. lamarckiana a range between 14.6 and $25.0 \%$ was found. Selection for higher oil content seems thus possible for these common types. The average results for the percentage of oil are shown in Table 1.

Five extracted seed samples of $O$. biennis were analysed for their remaining nutritional value. A rather low protein content (15\%) and high fiber content $(55 \%)$ were found, the remaining compounds being water, carbohydrates and minerals (Hudson, 1984).

\section{Fatty acid composition}

The fatty acids C16:0, C18:0, C18:1, C18:2 and GLeA (C18:3) in the oil obtained from the different species as well as the GLeA content in the seed are tabulated in Table 1. Fig. 1 illustrates the separation quality of the fatty acid analysis with capillary gas chromatography on CP WAX 57 CB of $B$. officinalis.

\section{Oenothera species}

The GLeA overall mean content in the oil was $10.5 \%$ (standard deviation 0.80 ). Linoleic acid (C18:2, n-6) was predominant and represented ca $72 \%$ of the total fatty acids. Minor fatty acids that are not included in Table 1 are: palmoleic acid (C16:1) $0.09 \%$; $\alpha$-linolenic acid (C18:3, n-3) 0.21\%; eicosanoic acid (C20:0)

${ }^{1}$ BCR; Rue de la Loi 200, Brussels, Belgium. 
Table 1. Contents of oil and principle fatty acids of 23 species of Oenothera and of B. officinalis, breeded in the Netherlands in 1986.

\begin{tabular}{|c|c|c|c|c|c|c|c|}
\hline \multirow[t]{2}{*}{$n^{1}$} & \multicolumn{5}{|c|}{ Fatty acids in oil $(\% \mathrm{w} / \mathrm{w})$} & \multirow{2}{*}{$\begin{array}{l}\text { Oil } \\
\text { in } \\
\text { seed } \\
(\% \mathrm{w} / \mathrm{w})\end{array}$} & \multirow{2}{*}{$\begin{array}{l}\text { C18:3 } \\
\text { GLeA } \\
\text { in seed } \\
(\% \mathrm{w} / \mathrm{w})\end{array}$} \\
\hline & $\overline{\mathrm{C} 16: 0}$ & C18:0 & $\mathrm{C} 18: 1$ & $\begin{array}{l}\text { C18:2 } \\
\text { LA }^{2}\end{array}$ & $\begin{array}{l}\text { C18:3 } \\
\text { GLeA }^{3}\end{array}$ & & \\
\hline
\end{tabular}

\section{Oenothera spp.}

\begin{tabular}{|c|c|c|c|c|c|c|c|c|}
\hline O. biennis & 14 & 7.0 & 1.5 & 7.7 & 72.0 & 10.5 & 20.1 & 2.1 \\
\hline O. hookeri & 4 & 7.0 & 1.4 & 7.6 & 72.6 & 10.3 & 23.3 & 2.4 \\
\hline O. lipsiensis & 1 & 7.1 & 1.4 & 5.6 & 74.4 & 10.6 & 24.0 & 2.6 \\
\hline O. caespitosa ${ }^{4}$ & 3 & 8.4 & 1.3 & 5.2 & 72.3 & 11.6 & 18.2 & 2.1 \\
\hline O. parviflora & 1 & 6.9 & 1.4 & 5.8 & 73.7 & 10.8 & 26.0 & 2.8 \\
\hline O. argillicola & 1 & 7.0 & 1.7 & 10.9 & 68.9 & 10.3 & 20.5 & 2.1 \\
\hline O. coronifera & 1 & 7.1 & 1.3 & 6.6 & 74.1 & 9.6 & 26.5 & 2.6 \\
\hline O. muricata & 2 & 8.2 & 1.6 & 8.0 & 69.2 & 11.7 & 19.4 & 2.3 \\
\hline O. wolfii & 1 & 7.1 & 1.2 & 6.4 & 74.0 & 10.1 & 25.4 & 2.6 \\
\hline O. ammophila & 3 & 7.0 & 1.7 & 6.7 & 71.0 & 12.4 & 21.3 & 2.6 \\
\hline$O$. erythrosepala & 2 & 7.0 & 1.6 & 9.3 & 70.4 & 10.1 & 16.4 & 1.6 \\
\hline O. lamarckiana & 13 & 7.1 & 1.4 & 8.2 & 71.6 & 10.2 & 22.1 & 2.3 \\
\hline O. densiflora & 1 & 8.0 & 1.7 & 8.9 & 69.9 & 10.3 & 21.2 & 2.2 \\
\hline$O$. gigas & 1 & 7.9 & 1.5 & 7.5 & 71.2 & 10.5 & 20.6 & 2.2 \\
\hline O. grandiflora & 2 & 7.4 & 1.7 & 6.8 & 72.1 & 10.7 & 19.9 & 2.1 \\
\hline O. francisciana $\times$ & & & & & & & & \\
\hline hookeri & 1 & 6.5 & 1.6 & 6.6 & 73.8 & 10.2 & 24.4 & 2.5 \\
\hline O. fallax $\times$ & & & & & & & & \\
\hline cambrice & 1 & 6.9 & 1.6 & 6.4 & 73.1 & 10.7 & 21.0 & 2.2 \\
\hline O. odorata ${ }^{4}$ & 1 & 7.4 & 1.6 & 6.1 & 72.6 & 10.9 & 20.5 & 2.2 \\
\hline O. perennis ${ }^{4}$ & 1 & 7.2 & 1.5 & 10.4 & 69.6 & 9.8 & 21.7 & 2.1 \\
\hline O. rubricaulis & 4 & 7.3 & 1.6 & 7.8 & 71.9 & 10.2 & 21.9 & 2.2 \\
\hline O. spectabilis & 1 & 7.7 & 1.6 & 6.8 & 72.5 & 10.3 & 20.4 & 2.1 \\
\hline O. $\times$ fallax & 1 & 7.9 & 1.6 & 6.6 & 71.9 & 10.3 & 17.0 & 1.8 \\
\hline O. francisciana & 2 & 6.9 & 1.5 & 6.0 & 73.7 & 10.7 & 22.7 & 2.4 \\
\hline $\begin{array}{l}\text { Mean value of } \\
\text { the } 23 \text { species }\end{array}$ & & 7.29 & 1.53 & 7.30 & 72.03 & 10.55 & 21.50 & 2.26 \\
\hline SD & & 0.473 & 0.136 & 1.462 & 1.616 & 0.624 & 2.623 & 0.270 \\
\hline \multicolumn{9}{|l|}{ Borago officinalis } \\
\hline Mean value & & 11.01 & 3.86 & 16.57 & 37.34 & 22.93 & 30.82 & 7.09 \\
\hline SD & & 0.748 & 0.464 & 1.714 & 0.922 & 1.800 & 2.837 & 1.041 \\
\hline
\end{tabular}

$1 n=$ number of accessions.

${ }^{2} \mathrm{LA}=$ linoleic acid.

${ }^{3}$ GLeA $=\gamma$-linolenic acid.

${ }^{4}$ Other than subgen Oenothera. 


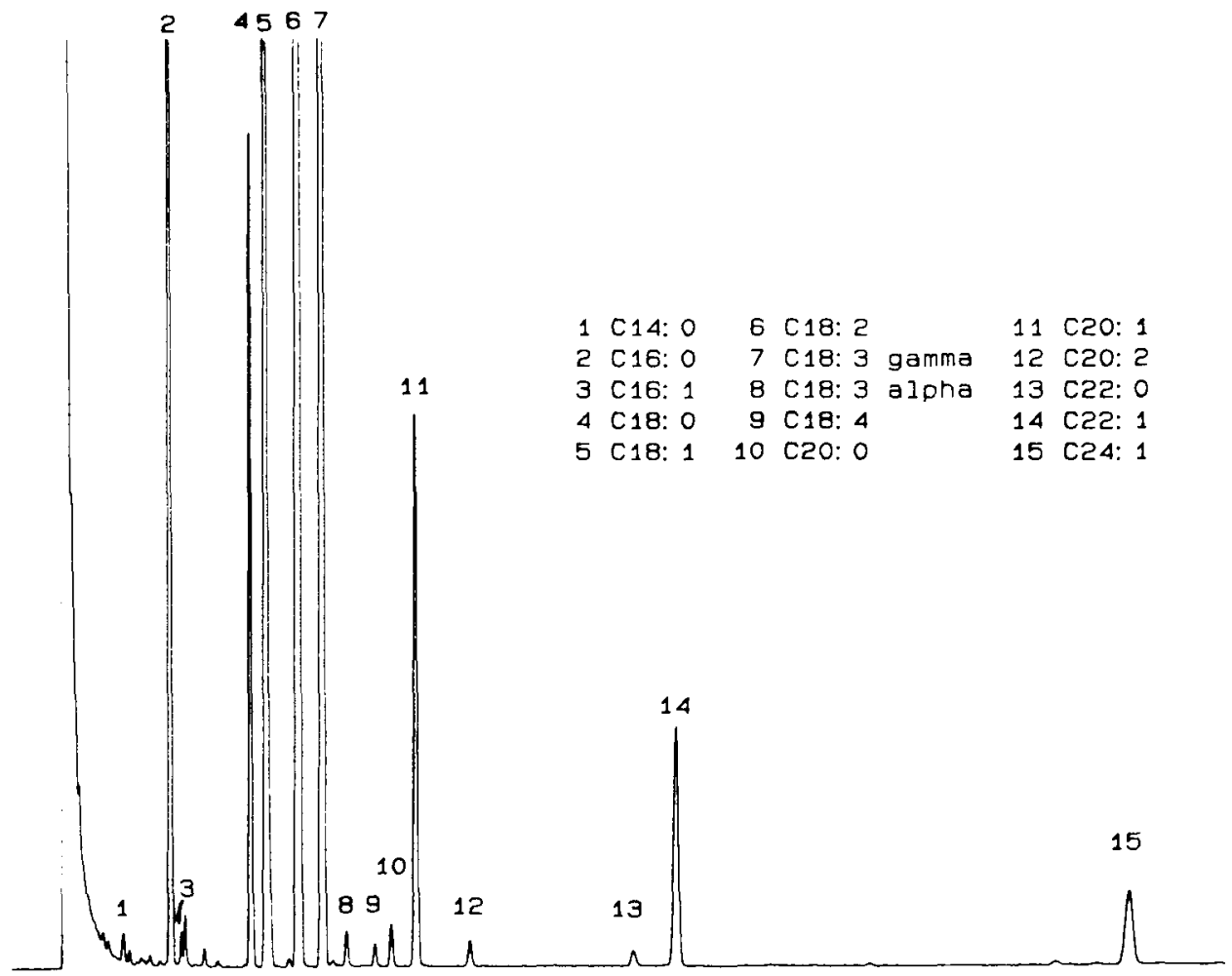

Fig. 1. Gas chromatogram of fatty acid methyl esters of the oil of Borago officinalis. Conditions: Varian 3700 with capillary column $\mathrm{Cp}$ Wax $57 \mathrm{cb}\left(25 \mathrm{~m} \times 0.22 \mathrm{~mm}\right.$ i.d.); split injection; $215^{\circ} \mathrm{C}$ isothermal.

$0.23 \%$; eicosenoic acid (C20:1) $0.15 \%$; and some other fatty acids $0.64 \%$. GLeA and the oil in the seed were correlated $(r=0.83)$ according to the linear regression equation $G=0.0878 F+0.366$, where $G$ is the GLeA content in the seed and $F$ is the oil content. Fig. 2 illustrates this relationship.

Half of the Oenothera species grew on sand and the other part on clay. Only very slight differences were found in the fatty acid composition and oil content. According to the Student's $t$-test, no significant difference $(P>0.05)$ in GLeA content was found between the two sites, nor for the five replicated accessions of Oenothera.

\section{Borago officinalis}

B. officinalis oil contained appreciably more GLeA (average $22.9 \%$ ), as compared to Oenothera species, while much lower levels of linoleic (C18:2) acid were found (mean value $37.3 \%$ ). Minor fatty acids did not differ much from that in Oenothera species: C16:1 (0.16\%); $\alpha$-linolenic acid $(0.29 \%)$; and C20:0 $(0.22 \%)$. More distinction was found for: C18:4 (n-6, all cis) (0.18\%); C20:1 (3.47\%); 


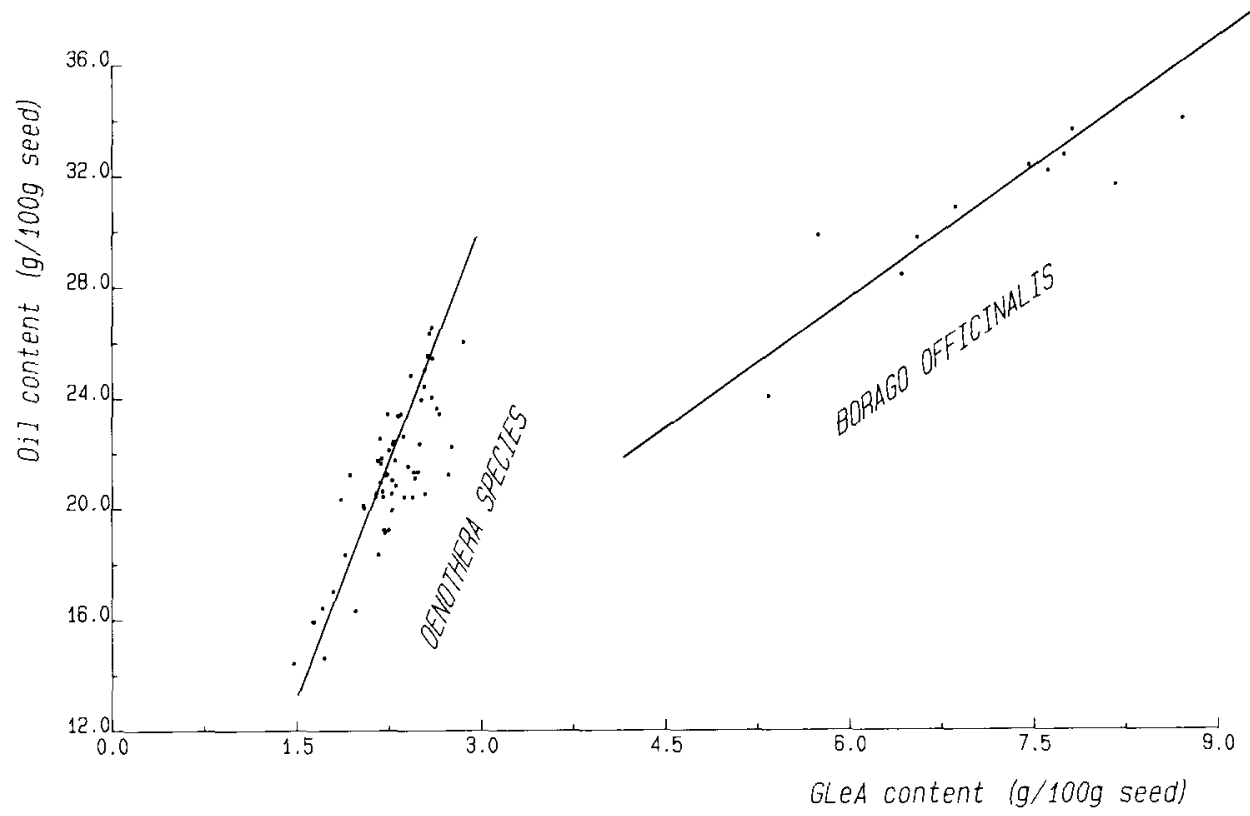

Fig. 2. Scattern diagram, with regression lines, of the relation between oil and gamma linolenic acid (GLeA) content of Borago officinalis and different species of Oenothera. Regression equations: GLeA $\%=0.323 \times$ oil $\%-2.876$ and GLeA $\%=0.0878 \times$ oil $\%+0.366$, respectively .

C22:1 (1.83\%); and C24:1 (0.95\%). These minor fatty acids also occur in other Boraginaceae species (Wolf et al., 1983; Kleiman et al., 1964). As with the Oenothera species a correlation $(r=0.88)$ exists between the GLeA content in the seed and the oil content for $B$. officinalis as illustrated in Fig. 2; the linear regression equation being: $G=0.323 F-2.876$, where $G$ is the GLeA content in the seed and $F$ is the oil content.

\section{Conclusions}

B. officinalis contains a higher GLeA content than Oenothera species. Considering similar seed yields (800-1400 $\mathrm{kg} \mathrm{ha}^{-1}$ ) for both crops, the higher contents of oil and GLeA of $B$. officinalis results in a three times higher GLeA production as compared with Oenothera species. However, the poor seed retention of $B$. officinalis is a negative factor to this assumption and the final influence on the profit is difficult to predict.

\section{References}

Dorp, D. A. van, 1983. My years in lipid research. Journal of the American Oil Chemists' Society 60: $1645-1648$. 


\section{OENOTHERA SPP. AND BORAGO OFFICINALIS AS SOURCES OF $\gamma$-LINOLENIC ACID}

Earle, F. R., E. H. Melvin, L. H. Mason, C. H. van Etten, I. A. Wolff \& Q. Jones, 1959. Search for new industrial oils. I. Selected oils from 24 plant families. Journal of the American Oil Chemists' Society 36: 304-307.

Gibson, R. A. \& G. M. Kneebone, 1981. Fatty acid composition of human colostrum and mature breast milk. The American Journal of Clinical Nutrition 34: 252-257.

Horrobin, D. F., M. S. Manku, S. Wright \& J. L. Burton, 1983. Abnormal essential fatty acid levels in patients with atopic eczema: successful treatment with evening primrose oil (EFAMOL). Journal of the American Oil Chemists' Society 60: 722. Abstract No 174.

Hudson, B. J. F., 1984. Evening primrose (Oenothera spp.) oil and seed. Journal of the American Oil Chemists' Society 61: 540-543.

IUPAC, 1978a. Preparation of the fatty acid methyl esters. Procedure 2.301. Standard methods for the analysis of oils, fats and derivatives, 6th ed., p. 96-100. Pergamon Press, Oxford.

IUPAC, 1978b. Gas-liquid chromatography of fatty acid methyl esters. Procedure 2.302. Standard methods for the analysis of oils, fats and derivatives, 6th ed., p. 103-108. Pergamon Press, Oxford.

Kleiman, R., F. R. Earle, I. A. Wolff \& Q. Jones, 1964. Search for new industrial oils. Oils of Boraginaceae. Journal of the American Oil Chemists' Society 41: 459-460.

Lacombe, A., O. Quenot, P. Grignac, J. Graille, M. Pina \& P. Garnier, 1985. Tentative de production d'acide gamma-linolenique par la culture de l'onagre (genre Oenothera). Oleagineux 40: 35-40.

Miller, R. W., F. R. Earle \& I. A. Wolff, 1968. Search for new seed oils. Oils of Boraginaceae. Lipids 3: 43-45.

Paccalin, J., H. Dabadie, M. Bernard, F. Mendy, D. Spielmann \& N. Delhaye, 1985. Intérêt d'une nouvelle plante oleagineuse: l'onagre. Apport en acide gamma-linolenique et troubles de la désaturation en pathologie. Médicine et Nutrition 21: 132-136.

Pina, M., J. Graille, P. Grignac, A. Lacombe, O. Quenot \& P. Granier, 1984. Recherche d'oenotheres riches en acide gamma-linolenique. Oleagineux 39: 593-596.

Soest, L. J. M. van, 1987. Introduction and preliminary evaluation of some potential industrial plants. In: Proceedings Workshop on evaluation of genetic resources for industrial purposes, p. 18-27. Ed. FAL, Braunschweig, BRD.

Traitler, H., H. Winter, U. Richli \& Y. Ingenbleek, 1984. Characterization of $\gamma$-linolenic acid in Ribes seed. Lipids 19: 923-928.

Wolf, R. B., R. Kleiman and R. E. England, 1983. New sources of $\gamma$-linolenic acid. Journal of the American Oil Chemists' Society 60: 1858-1860. 